\title{
Study on the Comprehensive Scoring Model for the Performance of Mergers \& Acquisitions with Related Party of Listed Companies
}

\author{
Lv Wenwen*
}

School of Economics and Management, Chuzhou University, Chuzhou, Anhui, 239002, China

\begin{abstract}
: since there are some special problems in the mergers \& acquisitions with related party in listed companies in China, it gradually becomes the hot issue among the economists. In this paper, a comprehensive scoring model is constructed on the basis of principal component analysis from the relationship between domestic and foreign M\&A practices and performance of listed companies. Empirical analysis is launched with the data of 100 listed companies executing the M\&A with related party in 2011 and 13 performance indexes selected from Shanghai and Shenzhen stock market, and finally, the comprehensive model applied for 7 principal component sand calculation and scoring is determined. The final comprehensive scoring results show that the corporate performance will decline remarkably in the same year of the implementation of M\&A with related party, and it would rise again a year later. It also indicates that there are indeed some improper operations in the M\&A with related party of listed companies, which may frustrate the minority shareholders and vast employees, and result in the declining performance after the M\&A with related party.
\end{abstract}

Keywords: Comprehensive grading, principal component analysis (PCA), corporate performance, listed companies, mergers and acquisitions (M\&A) with related party.

\section{LITERATURE REVIEW}

In other countries, M\&A behaviors will usually promote the improvement of performance of listed companies. However, in China, M\&A with related party may not improve the performance of the company in most cases, and the cause has drawn extensive attention from the economists.

In foreign countries, the study on the M\&A behaviors and performance of listed companies started early, and it formed comparatively systematic theories in the end of last century. Schwert conducted studies on the M\&A behaviors of more than 200 listed companies in England according to the related data from the end of $1960 \mathrm{~s}$ to the beginning of $1970 \mathrm{~s}$, and discovered that the M\&A behaviors may promote the improvement of return on total assets of the original listed companies [1]. Jensen divided the M\&A behaviors into the vertical M\&A behaviors, horizontal M\&A behaviors and mixed M\&A behaviors, and discovered through the study on the M\&A behaviors of nearly 300 listed companies that vertical and horizontal M\&A behaviors can enhance the improvement of corporate performance, but the mixed M\&A behaviors may decline the corporate performance [2]. Bruner counted the related data of $50 \mathrm{M} \& \mathrm{~A}$ behaviors in America and launched the empirical analysis, and showed that the M\&A behaviors of listed companies may promote the improvement of corporate performance remarkably [3]. Bae compared and analyzed more than $10 \mathrm{M} \& \mathrm{~A}$ activities in America and discovered that listed companies can gain extra $30 \%$ of the unexpected income through M\&A, and it is the key to the improvement of corporate performance after M\&A [4]. John conducted studies similar to Bae's, and concluded that M\&A behaviors of listed companies can gain at least more than $10 \%$ of the yield advantage, which may promote the corporate in gaining higher profits [5].

Compared to the foreign scholars, domestic scholars started relatively late in the study on the relationship between the M\&A behaviors and corporate performance. Fang Hong conducted the studies on the M\&A behaviors of more than 300 listed companies in Shenzhen and Shanghai Stock Market, and discovered that the M\&A behaviors may help increase the shareholder's wealth, but there were no explicit reflections on the shareholders of the acquired company [6]. Zhou Xingwang selected the M\&A behaviors of nearly 60 listed companies in Shanghai and Shenzhen Stock Market from 2000 to 2002 for analysis, and summarized that the M\&A behaviors may bring severe negative impact on the acquiring companies, and result in the declining corporate performance [7]. It is exactly opposite to the results of Fang Hong. Zhu Dongqin conducted the empirical analysis for the M\&A behaviors of listed companies in five years since 1998, and discovered that such M\&A behaviors were similar to the emptying practices, which would not improve the corporate performance, but also bring huge economic loss to the small shareholders [8]. Cai Weixing's study was similar to Jensen's. He discovered from related data of M\&A behaviors of listed companies in China that horizontal M\&A can improve the performance of listed companies within a certain range, and other forms of M\&A behaviors have no distinct impact on the corporate performance [9]. Wu Lijun investigated the performance of listed companies before and after the M\&A in different years, and discovered that the performance of 
listed company would be improved in the same year of M\&A, but it would decline evidently after the M\&A, suggesting that the M\&A has a negative impact on the corporate performance in the long run [10]. Many other domestic scholars also concluded that the M\&A behaviors have negative impact on the performance of listed companies.

Studies are conducted by aiming at the M\&A with related party of listed companies in China on the basis of previous research achievements. Meanwhile, the relationship between the M\&A with related party and performance of listed companies is explored with the assistance of PCA-based comprehensive scoring model by comparing the performance before and after the M\&A.

\section{PCA-BASED COMPREHENSIVE SCORING MODEL}

The study on the relationship between the M\&A with related party and corporate performance will certainly involve several items of economic data of several years and several listed companies. As for the credibility and effectiveness of the study, the reliability of data can be tested through the Cronbach coefficient analysis method, while validity of data can be tested with KMO measure test and Bartlett sphericity test.

Cronbach coefficient analysis method is a typical structure reliability analysis method, and the specific mathematical formula is shown as follows.

$\alpha=\frac{K}{K-1}\left(1-\frac{\sum S_{i}^{2}}{S_{T}^{2}}\right)$

Validity analysis mainly obtains the validity result according to the KMO detection value and Bartlett sphericity test result. If KMO is over 0.7 , and the Bartlett sphericity is smaller than 0.05 , it means that the statistical data has high availability.

In the statistical analysis, if there are too many original statistical variables, it may be difficult for the statistical work, and at this moment, it shall extract the principal component with PCA, for simplifying the follow-up data processing. In the entire statistical work, there are $n$ original variables, and then each original variable can be expressed as the linear combination of principal component, as shown in equation (2).

$$
\left\{\begin{array}{c}
Z_{1}=a_{11} F_{1}+a_{12} F_{2}+\cdots+a_{1 m} F_{m}+U_{1} \\
Z_{2}=a_{21} F_{1}+a_{22} F_{2}+\cdots+a_{2 m} F_{m}+U_{2} \\
\cdots \\
Z_{j}=a_{j 1} F_{1}+a_{j 2} F_{2}+\cdots+a_{j m} F_{m}+U_{j} \\
\cdots \\
Z_{n}=a_{n 1} F_{1}+a_{n 2} F_{2}+\cdots+a_{n m} F_{m}+U_{n}
\end{array}\right.
$$

In the equation, stands for the principal component of each variable, stands for the individual componnt of each component, stands for the loadng coefficient of the principal component in different variables, and all form the factor loading matrix, as shown in equation (3).

$$
A=\left[\begin{array}{cccc}
a_{11} & a_{12} & \cdots & a_{1 m} \\
a_{21} & a_{22} & \cdots & a_{2 m} \\
\vdots & \vdots & & \vdots \\
a_{n 1} & a_{n 2} & \cdots & a_{n m}
\end{array}\right]
$$

At this moment, the contribution degree of each principal component to each variable is determine by judging the loading coefficient in loading matrix A, and the burden of follow-up calculation shall be alleviated through eliminating these minor constituents. This model is also the mathematical model for the empirical study.

\section{EMPIRICAL ANALYSIS OF THE IMPACT OF M\&A WITH RELATED PARTY ON THE CORPO- RATE PERFORMANCE}

\subsection{Variable Selection}

In this paper, the thought of empirical analysis is to deal with the performance of listed companies in the year before M\&A, the year of M\&A and the year after M\&A with the comprehensive scoring model, and to judge the rise and fall of the comprehensive scoring of performance. Therefore, the selection of variables as the representative variables of corporate performance turns to be the foundation of empirical analysis.

The performance evaluation of listed companies generally includes the profitability, debt repayment level, development level and operation level, etc. from which, 13 variables are selected as the fundamental variables of empirical analysis, as shown in Table $\mathbf{1}$.

After the fundamental variables of empirical analysis are obtained, 100 listed companies implementing M\&A with related party in 2011 are selected from the Database for the Study on the M\&A and Asset Restructuring of Listed Companies, and data statistics is conducted for the 2010, 2011 and 2012 according to Table $\mathbf{1}$. The specific data condition is shown in Table 2.

It can be seen from the M\&A performance of the 100 listed companies in 2010, 2011 and 2012 that the operating yield, return on equity, return on total assets and single share yield of 2010 was $0.131,0.139,0.081$ and 0.512 respectively, while that of 2011 was $0.127,0.116,0.042$ and 0.421 respectively. Compared to 2010 , the four indexes presented a declining trend, suggesting that the corporate performance in the same year of M\&A declined remarkably. In 2012, it was $0.113,0.121,0.054$ and 0.461 respectively, among which, the last three indexes increased a little compared to 2011, suggesting that the corporate performance was improved in the year after the M\&A.

The comparison in indexes cannot illustrate the changes in the performance of listed companies before and after the M\&A. Therefore, empirical analysis is further conducted with the comprehensive scoring model stated in the second chapter of this paper.

\subsection{Empirical Analysis}

Before conducting the principal component analysis for getting the comprehensive evaluation model, reliability 
Table 1. Fundamental variables of the performance evaluation of listed companies.

\begin{tabular}{|c|c|c|c|}
\hline First-Level Index & Second-Level Index & Variables & Calculation Basis \\
\hline \multirow{5}{*}{ Profitability } & Operating yield & $\mathrm{P} 1$ & Net operating income / Total operating income \\
\hline & Return on equity & P2 & Net income / Net asset \\
\hline & Return on total assets & P3 & Net income / Net asset balance \\
\hline & Single share yield & P4 & Net income / Total shares \\
\hline & Single share cash profitability & P5 & Net cash flow amount / Total stocks \\
\hline \multirow{3}{*}{ Debt repayment level } & Quick ratio of debt payment & P6 & (Current asset - inventory) / Total liabilities \\
\hline & Current ratio of debt payment & P7 & Current asset / Total liability \\
\hline & Debt ratio & P8 & Total liability / Total asset \\
\hline \multirow{3}{*}{ Development level } & Single net asset increasing rate & P9 & $\begin{array}{l}\text { Asset value of single share of the current period / Asset } \\
\text { value of single share of last period -1 }\end{array}$ \\
\hline & Growth rate of operating income & $\mathrm{P} 10$ & $\begin{array}{l}\text { (Operating income of the current period - Operating in- } \\
\text { come of last period) / Operating income of last period }\end{array}$ \\
\hline & Net profit growth rate & P11 & $\begin{array}{l}\text { (Net income of the current period - Net income of last } \\
\text { period) / Net income of last period }\end{array}$ \\
\hline \multirow{2}{*}{ Operation level } & Inventory turnover ratio & $\mathrm{P} 12$ & Operating income / Total inventories \\
\hline & Total asset turnover & $\mathrm{P} 13$ & Operating income / Average total asset \\
\hline
\end{tabular}

Table 2. Performance assessment data of 100 listed companies about a year before the M\&A with related party (2010).

\begin{tabular}{|c|c|c|c|c|c|}
\hline Variables & Number of Companies & Minimum Value & Maximum Value & Average Value & Variance \\
\hline $\mathrm{P} 1$ & 100 & -0.119 & 2.231 & 0.131 & 0.191 \\
\hline $\mathrm{P} 2$ & 100 & -0.068 & 0.517 & 0.139 & 0.107 \\
\hline P3 & 100 & -0.047 & 1.802 & 0.081 & 0.127 \\
\hline $\mathrm{P} 4$ & 100 & -0.252 & 4.287 & 0.512 & 0.612 \\
\hline P5 & 100 & -4.698 & 10.011 & 0.635 & 1.307 \\
\hline P6 & 100 & 0.168 & 6.723 & 1.001 & 0.913 \\
\hline P7 & 100 & 0.233 & 8.299 & 1.522 & 1.182 \\
\hline P8 & 100 & 0.041 & 0.848 & 0.526 & 0.168 \\
\hline P9 & 100 & -79.271 & 175.417 & 1.618 & 15.072 \\
\hline $\mathrm{P} 10$ & 100 & -0.882 & 150.173 & 1.689 & 11.577 \\
\hline P11 & 100 & -2.671 & 242.576 & 4.132 & 23.098 \\
\hline $\mathrm{P} 12$ & 100 & 0.001 & 144.327 & 9.587 & 18.687 \\
\hline $\mathrm{P} 13$ & 100 & 0.003 & 8.773 & 1.023 & 0.933 \\
\hline
\end{tabular}


Table 3. Performance assessment data of 100 listed companies in the same year of M\&A with related party (2011).

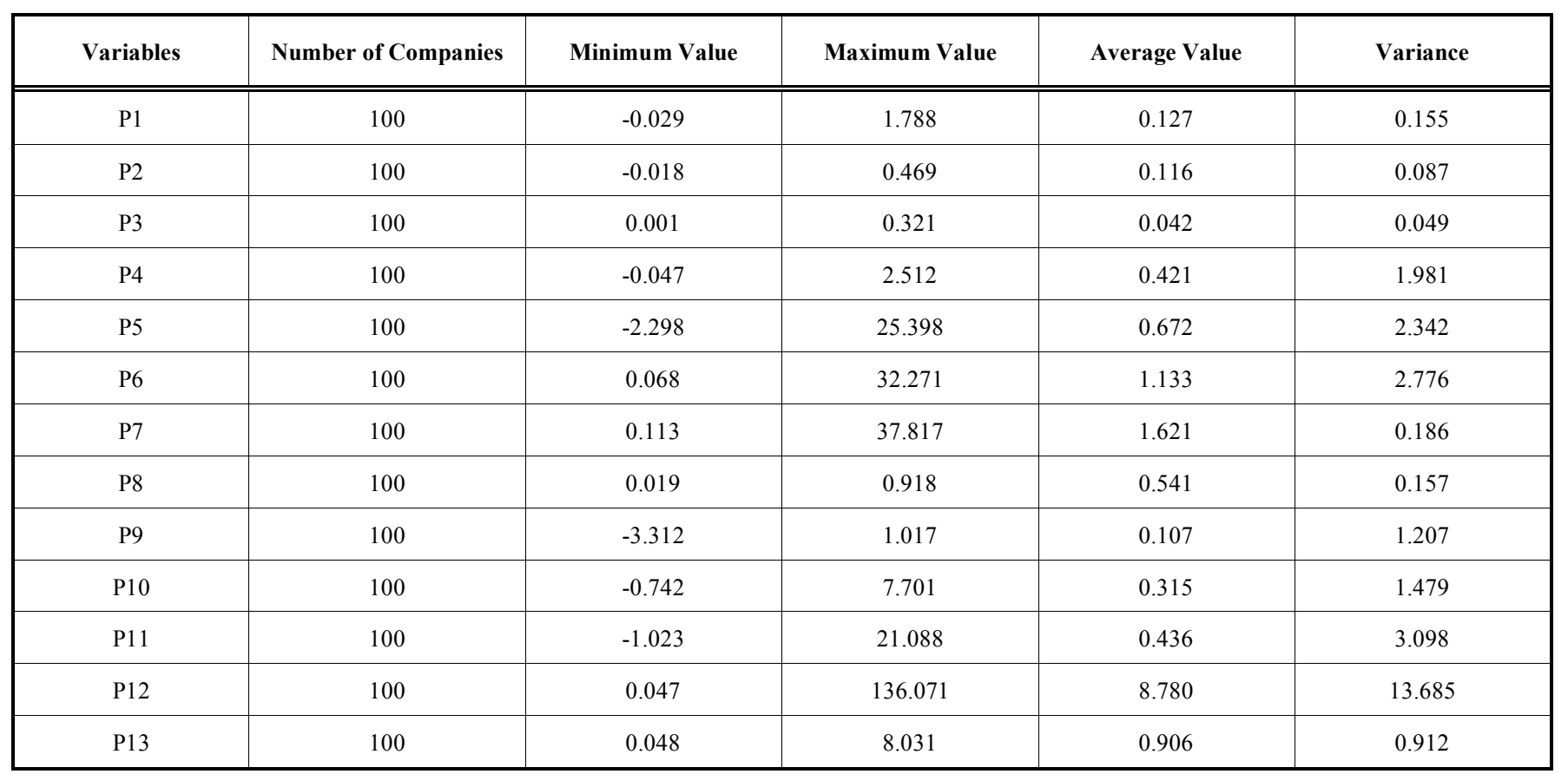

Table 4. Performance assessment data of 100 listed companies in the same year of M\&A with related party (2012).

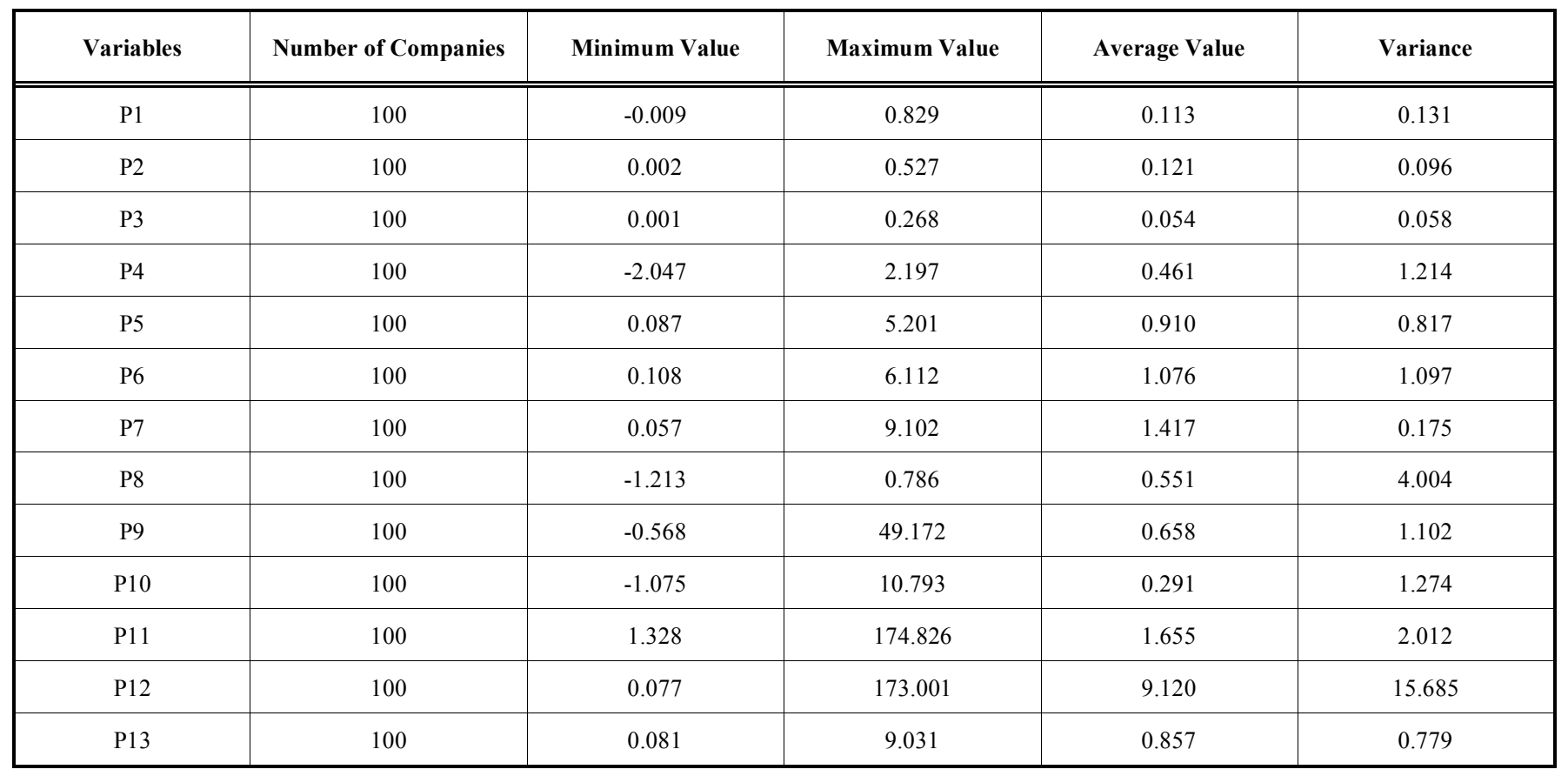

analysis, KMO measure test and Bartlett sphericity test are conducted and it turned out that the Cronbach coefficient of 13 indexes from 2010 to 2012 all exceeds 0.7 , proving the credibility of statistical data. The KMO measure test coefficient of the 13 indexes in the three years all exceeds 0.8 and the Bartlett sphericity is smaller than 0.05 , proving the availability of statistical data. The work shows that the data in Tables 2-4 can be applied in the principal component analysis.
In this way, principal component analysis is conducted in SPSS, and the principal component loading condition of the original 13 variables can be obtained, as shown in Table 5.

According to the result of the principle component analysis, the seven principal components can be calculated with the original 13 performance assessment variables. Specifically: 
Table 5. Principal component expression of 13 variables obtained in SPSS.

\begin{tabular}{|c|c|c|c|c|c|c|c|}
\hline \multirow{2}{*}{ Variables } & \multicolumn{7}{|c|}{ Principal Component } \\
\hline & F1 & F2 & F3 & F4 & F5 & F6 & F7 \\
\hline $\mathrm{P} 1$ & 0.161 & -0.128 & -0.089 & -0.388 & 0.432 & -0.012 & -0.278 \\
\hline $\mathrm{P} 2$ & 0.231 & 0.227 & -0.171 & -0.027 & -0.077 & -0.176 & 0.162 \\
\hline P3 & 0.317 & 0.088 & -0.084 & -0.072 & 0.061 & -0.084 & 0.041 \\
\hline $\mathrm{P} 4$ & 0.214 & 0.199 & -0.201 & -0.038 & -0.148 & 0.051 & 0.133 \\
\hline P5 & 0.029 & 0.228 & -0.058 & 0.072 & -1.208 & 0.632 & -0.227 \\
\hline P6 & 0.213 & 0.217 & 0.159 & 0.162 & -1.998 & 0.162 & 0.063 \\
\hline P7 & 0.214 & 0.201 & 0.174 & 0.057 & -2.157 & 0.113 & 0.091 \\
\hline P8 & -0.189 & 0.192 & -0.130 & 0.009 & -2.135 & -0.047 & 0.244 \\
\hline P9 & 0.047 & 0.191 & 0.329 & 0.042 & 0.130 & -0.401 & 0.158 \\
\hline P10 & -0.154 & 0.234 & 0.254 & 0.029 & -0.128 & 0.423 & -0.201 \\
\hline P11 & 0.257 & -0.035 & 0.401 & 0.043 & 0.061 & -0.135 & 0.044 \\
\hline P12 & -0.119 & 0.056 & 0.029 & 0.431 & 0.472 & 0.361 & 0.801 \\
\hline P13 & 0.021 & 0.029 & -0.083 & 0.521 & -0.172 & -0.235 & -0.234 \\
\hline
\end{tabular}

$\mathrm{F} 1=0161 \mathrm{P} 1+0.231 \mathrm{P} 2+0.0317 \mathrm{P} 3+0.214 \mathrm{P} 4+0.029 \mathrm{P} 5+0.213 \mathrm{P} 6+0.214 \mathrm{P} 7$ $-0.189 \mathrm{P} 8+0.047 \mathrm{P} 9-0.154 \mathrm{P} 10+0.257 \mathrm{P} 11-0.119 \mathrm{P} 12+0.021 \mathrm{P} 13$

$\mathrm{F} 2=-0.128 \mathrm{P} 1+0.227 \mathrm{P} 2+0.088 \mathrm{P} 3+0.199 \mathrm{P} 4+0.228 \mathrm{P} 5+0.217 \mathrm{P} 6+0.201 \mathrm{P} 7$ $+0.192 \mathrm{P} 8+0.191 \mathrm{P} 9+0.234 \mathrm{P} 10-0.035 \mathrm{P} 11+0.056 \mathrm{P} 12+0.029 \mathrm{P} 13$

$\mathrm{F} 3=-0.089 \mathrm{P} 1-0.171 \mathrm{P} 2-0.084 \mathrm{P} 3-0.201 \mathrm{P} 4-0.058 \mathrm{P} 5+0.159 \mathrm{P} 6+0.174 \mathrm{P} 7$ $-0.130 \mathrm{P} 8+0.329 \mathrm{P} 9+0.254 \mathrm{P} 10+0.401 \mathrm{P} 11+0.029 \mathrm{P} 12-0.083 \mathrm{P} 13$

$\mathrm{F} 4=-0.388 \mathrm{P} 1-0.027 \mathrm{P} 2-0.072 \mathrm{P} 3-0.038 \mathrm{P} 4+0.072 \mathrm{P} 5+0.162 \mathrm{P} 6+0.057 \mathrm{P} 7$ $+0.009 \mathrm{P} 8+0.042 \mathrm{P} 9+0.029 \mathrm{P} 10+0.043 \mathrm{P} 11+0.431 \mathrm{P} 12+0.521 \mathrm{P} 13$

$\mathrm{F} 5=0.432 \mathrm{P} 1-0.077 \mathrm{P} 2+0.061 \mathrm{P} 3-0.148 \mathrm{P} 4-1.208 \mathrm{P} 5-1.998 \mathrm{P} 6-2.157 \mathrm{P} 7$ $-2.135 \mathrm{P} 8+0.130 \mathrm{P} 9-0.128 \mathrm{P} 10+0.061 \mathrm{P} 11+0.472 \mathrm{P} 12-0.172 \mathrm{P} 13$

$\mathrm{F} 6=-0.012 \mathrm{P} 1-0.176 \mathrm{P} 2-0.176 \mathrm{P} 3-0.084 \mathrm{P} 4+0.051 \mathrm{P} 5+0.632 \mathrm{P} 6+0.162 \mathrm{P} 7$ $+0.113 \mathrm{P} 8-0.047 \mathrm{P} 9+0.423 \mathrm{P} 10-0.135 \mathrm{P} 11+0.361 \mathrm{P} 12-0.235 \mathrm{P} 13$

$\mathrm{F} 7=-0.278 \mathrm{P} 1+0.162 \mathrm{P} 2+0.041 \mathrm{P} 3+0.133 \mathrm{P} 4-0.227 \mathrm{P} 5+0.063 \mathrm{P} 6+0.091 \mathrm{P} 7$ $+0.244 \mathrm{P} 8+0.158 \mathrm{P} 9-0.201 \mathrm{P} 10+0.044 \mathrm{P} 11+0.801 \mathrm{P} 12-0.234 \mathrm{P} 13$

In this way, the comprehensive score of the performance assessment of 100 listed companies in 2010 can be calculated in the following equation:

$Q_{2010}=\frac{0.21236 \mathrm{~F} 1+0.18007 \mathrm{~F} 2+0.15172 \mathrm{~F} 3+0.10572 \mathrm{~F} 4+0.08001 \mathrm{~F} 5+0.07533 \mathrm{~F} 6+0.06321 \mathrm{~F} 7}{0.86842}$ Similar to a series of above deduction, the comprehensive scoring of 100 listed companies in 2011 and 2012 can be calculated in the following equation:

$Q_{2011}=\frac{0.24811 \mathrm{~F} 1+0.17601 \mathrm{~F} 2+0.13920 \mathrm{~F} 3+0.10572 \mathrm{~F} 4+0.08041 \mathrm{~F} 5+0.06671 \mathrm{~F} 6+0.05959 \mathrm{~F} 7}{0.8754}$ $Q_{2012}=\frac{0.22391 \mathrm{~F} 1+0.16724 \mathrm{~F} 2+0.13587 \mathrm{~F} 3+0.10499 \mathrm{~F} 4+0.08120 \mathrm{~F} 5+0.06971 \mathrm{~F} 6+0.06723 \mathrm{~F} 7}{0.85926}$

With the data and equation (5) (6) and (7) in table 2-4, the comprehensive scoring of the performance of listed companies in 2010, 2011 and 2012 is $0.002173,0.001069$ and 0.001352 respectively. It shows that the comprehensive scoring method obtains the same conclusion of direct evaluation with data statistics, namely the corporate performance of listed company after the M\&A with related party would decline remarkably, but it would increase a little a year after the M\&A with related party.

\section{CONCLUSION}

Since the listed companies in China are transformed from the state-owned enterprises, the ownership structure of listed companies is not quite appropriate. In recent years, largescale M\&A behaviors of listed companies have been launched, aiming to achieve more proper ownership structure and better corporate performance. But actually, the M\&A of listed companies is more of the M\&A with related party, namely the merger and reorganization conducted between the listed company and related party.

In order to explore the effects in corporate performance after the M\&A with related party, the PCA-based comprehensive scoring method is constructed, and 100 listed companies implementing the M\&A with related party in 2011 were selected, for calculating the corporate performance in 2010, 2011 and 2012 respectively.

In the empirical analysis process, 7 principal components are extracted from the originally selected 13 performance assessment variables, and the performance comparison result of the three years shows that the performance of listed companies implementing the M\&A with related party declines evidently in the same years, and it may increase slightly in the next years, suggesting that there are still many problems in the implementation of M\&A with related party, and there are also other problems, such as the emptying of minority shareholders, deformity reorganization, malicious merger, etc. which may impact the improvement of corporate performance. 


\section{CONFLICT OF INTEREST}

The authors confirm that this article content has no conflict of interest.

\section{ACKNOWLEDGEMENTS}

Declared none.

\section{REFERENCES}

[1] G. W. Schwert, "Markup pricing in mergers and acquisitions," Journal of Financial Economics, vol. 41, pp. 153-192, 1996.

[2] M. Jensen, and R.S. Ruback, "The market for corporate control: the scientific evidnce," Journal of Finacila Economics, vol. 11, pp. 550, 2003.

[3] R. F. Bruner, "Does M and A pay: a survey of evidence for the decision maker," Journal of Applied Economics, vol. 12, pp. 48-68, 2009.

[4] K.H. Bae, K.K. Jun, and M.K. Jin, "Tunneling or value added? Evidence from mergers by Korean business groups," Journal of Finance, vol. 57, pp. 2695-2740, 2012.
[5] S.W. Joh, "Corporate governance and firm profitability: evidence from Korean before the economic crisis," Journal of Financial Economics, vol. 68, pp. 287-322, 2010.

[6] H. Fang, "Research Overview of Private Income and M\&A Performance of Major Shareholders," Securities and Futures of China, vol. 2, pp. 44-49, 2011.

[7] X. Zhou, Q. Zhang, and F. Wan, "Analysis of the Perplexity in M\&A Performanceof China Listed Company," Journal of Wuhan University of Technology (Social Sciences Edition), vol. 2, pp. 79$86,2010$.

[8] D. Zhu, and W. Chen, "Effects of control right and the deviation between control right and cash flow right on acquisitions: evidence from private listed companies in china," Journal of Finace and Ecnomics, vol. 2, pp. 111-120, 2010.

[9] W. Cai, and M. Gao, "Ultimate owner's ownership, control rights and expropriation: evidence from related-party transactions," South China Journal of Economics, vol. 2, pp. 227-231, 2010.

[10] L. Wu, "Impact of Control Right Characteristics on the M\&A Performance of Private Listed - On the basis of EVA Index," Zhejiang: Zhejiang Gongshang University, 2009.

(C) Lv Wenwen; Licensee Bentham Open.

This is an open access article licensed under the terms of the Creative Commons Attribution Non-Commercial License (http://creativecommons.org/licenses/by-nc/3.0/) which permits unrestricted, non-commercial use, distribution and reproduction in any medium, provided the work is properly cited. 